\title{
Increasing of Wet Noodles Quality Using Vegetables Oil Coating
}

\author{
Nurhayati Nurhayati ${ }^{1, *}$, Maria Belgis ${ }^{1}$, Jay Jayus ${ }^{1}$, Infidzah S. Velianti ${ }^{1}$ \\ ${ }^{1}$ Department of Agricultural Products Technology, Universitas Jember, Jember, 68121, Indonesia \\ *Corresponding author.Email: Nurhayati.ftp@unej.ac.id
}

\begin{abstract}
Wet noodles are often used as the main ingredient in making chicken noodles, which is one of the favorite foods like Indonesian. The process of making wet noodles without going through the drying stages makes the noodles easily damaged by microbial growth such as bacteria. This study evaluated the effect of using coconut oil as a noodle coating on the quality of noodles by comparing it with other vegetable oils. The oils were coconut oil, corn oil, soybean oil, olive oil, and palm oil. The coating of vegetable oil on wet noodles was carried out as much as $5 \%$ of the total weight of wet noodles used. Wet noodles were made from wheat flour, and other ingredients. Wet noodles were analyzed including texture, moisture content, elasticity, organoleptic, and total microbial. Total microbe on coated wet noodles was higher than coated vegetable oil. The lowest bacterial contamination was in wet noodles coated with coconut oil as much as $1.12 \log \mathrm{CFU} / \mathrm{g}$. Wet noodles have a more chewy and elastic texture after being smeared with vegetable oil. The type of vegetable oil does not affect the sensory value of wet noodles for aroma, color, texture, taste preferences. It is recommended that noodles must be consumed before $48 \mathrm{~h}$ storage.
\end{abstract}

Keywords: Biosafety, Microbial population, Noodles, Sensory evaluation.

\section{INTRODUCTION}

Public awareness of food safety must be increased. Several cases of food safety occurred, such as the use of prohibited chemicals such as formalin as a food preservative in instant noodle products, meatballs, fish and others. Formalin is intended for non-food industries as a soldering agent, cleaning agent, wood preservative, and antiseptic[1]. Cases of use of formalin occur in wet noodles. This is because formalin is very easy and cheap.

Wet noodles require preservatives to prevent damage with a relatively high moisture content of $35 \%-52 \%$ so that their shelf life is relatively short and easily damaged[2]. Alternative natural ingredients as safe preservatives include vegetable oil. Some vegetable oils contain the lauric acid that was known as antimicrobial[3]. Lauric acid in coconut oil reaches $61.93 \%$ [4]. Corn oil consists of $59 \%$ poly-unsaturated (PUFA), 24\% mono-unsaturated (MUFA), and 13\% saturated fatty acids (SFA). Corn oil has the highest PUFA level after sunflower, safflower, walnut and wheat germ oil. Corn oil contains high amounts of ubiquinone and gamma-tocopherol (Vitamin E). PUFA and vitamin $\mathrm{E}$ from corn oil consumption can provide health benefits[5]. This study evaluated the level of biosafety in wet noodles coated with vegetable oil based on the value of microbial contamination.

There are two type of noodles i.e Chinese and Japanese type noodles. Chinese type noodles are made from hard wheat flour with bright creamy white or bright yellow color and firm texture. Japanese noodles are made from soft wheat flour of medium protein with creamy white color and a soft and elastic texture[6]. Many varieties of noodle type have different characteristics that represent the different formulation and the processing. This research produced Japanese type noodles that use medium protein-wheat flour and egg to get a soft and elastic texture.

\section{MATERIALS AND METHOD}

\subsection{Materials}

Wet noodles were made from wheat flour, salt, eggs, and water as well as vegetable oil for coating (coconut oil, corn oil, soybean oil, olive oil, palm oil). The medium for microbial plating is PCA (Plate Count Agar) (MERCK 105463), and SCA (Salmonella Chromogenic Agar) (Himedia M108-500G). The tool for noodles uses 
a noodle printer (brand OX-355AT) with a diameter of 2 $\mathrm{mm}$, analytical balance (AS220 R2 Internal).

\subsection{Experimental Design}

The research on making noodles was designed using a completely randomized design (CRD) with one factor, namely the type of vegetable oil. Vegetable oils used are coconut oil, corn oil, soybean oil, olive oil, and palm oil. The stages of the research include the stage of making wet noodles, the stage of the storage model, the stage of evaluating the level of biosafety based on microbial contamination.

\subsection{Noodle Making}

Noodle making was done by mixing wheat flour, salt, and water little by little until evenly homogenized. Then added the egg, then the dough was kneaded again for 15 minutes until smooth, then the noodle dough was printed. Next, the noodles were boiled for 2 minutes at $100{ }^{\circ} \mathrm{C}$ while stirring slowly until cooked[7]. Next, the cooked noodles were drained and smeared with $5 \%$ w/w coconut oil/corn oil/soybean oil/olive oil/and palm oil. The storage model stage was carried out by packing the wet noodles in ziplock plastic and stored at room temperature for 48 hours. The evaluation stage of the biosafety level of wet noodles was carried out by calculating the population of microbial contamination in wet noodles without storage and storage ( 24 hours). Sensory changes were observed during storage.

\subsection{Parameter Analysis}

The level of biosafety was observed based on the microbial population and bacterial contamination using BAM method[8] that presented by survival percentage[9;10;11]. Parameters to determine the effect of the use of vegetable oil on the characteristics of noodles included water content, texture, elasticity, and sensory properties. The sensory characteristics of wet noodles were evaluated in a preference test[12] and shown as radar figure[13].

\section{RESULTS AND DISCUSSION}

\subsection{Biosafety level of wet noodle coating by vegetables oil}

The lowest population of microbial contamination occurred on wet noodles coated with coconut oil, namely $1.78 \log 10 \mathrm{CFU} / \mathrm{mL}$ at 0 hours and $2.33 \log 10 \mathrm{CFU} / \mathrm{mL}$ after 48 hours storage (Figure 1). The highest population of microbial contamination occurred in control-treated wet noodles that were not coated with vegetable oil, namely $2.38 \log 10 \mathrm{CFU} / \mathrm{g}$ at 0 hours and $2.70 \log 10$ CFU/g after 48 hours storage. Suardana \& Swacita
(2009) reported that the factors that greatly affect the growth of microbial contaminants in the food are water activity (aw), time, temperature, and $\mathrm{pH}$. Wet noodles have a $\mathrm{pH}$ of 6-8 which is quite a wide range of types of microbial contamination from bacteria, yeast and molds. Storage for 48 hours does not increase the growth of microbial contamination on wet noodles coated with vegetable oil, especially coconut oil. The Indonesian national standard reports that the maximum amount of microbial contamination on wet noodles is no more than $10^{6} \mathrm{CFU} / \mathrm{g}$ or $6 \log 10 \mathrm{CFU} / \mathrm{g}$.

Examination of bacterial contamination, especially enteric bacteria, is an indicator of sanitation. The analysis use differential medium agar (Salmonella Chromogenic Agar) for determining the kind of enteric bacterial contaminants. Figure 2 presents the bacterial population in wet noodles stored for 24 hours and 48 hours. Vetter and Schlievert, (2005) also reported that lauric acid, capric acid and myristic acid in coconut oil are very useful as anti-bacterial. The lowest population of microbial contamination occurred in wet noodles coated with coconut oil, namely $1.12 \log 10 \mathrm{CFU} / \mathrm{mL}$ at 0 hours and $1.31 \log 10 \mathrm{CFU} / \mathrm{mL}$ at 48 hours. The highest population of bacterial contamination occurred in control-treated wet noodles that were not coated with vegetable oil, namely $1.79 \log 10 \mathrm{CFU} / \mathrm{g}$ at 0 hours and $2.08 \log 10 \mathrm{CFU} / \mathrm{g}$ at 48 hours. Storage at room temperature was able to increase the growth of microbial bacteria in wet noodles up to $2 \log$ cycles. However, the wet noodles coated with vegetable oil did not reach $1 \mathrm{log}$ cycle. Wet noodles have a long range of $\mathrm{pH}$ that is quite a wide range of the types of microbial contamination from bacteria, yeast and molds.

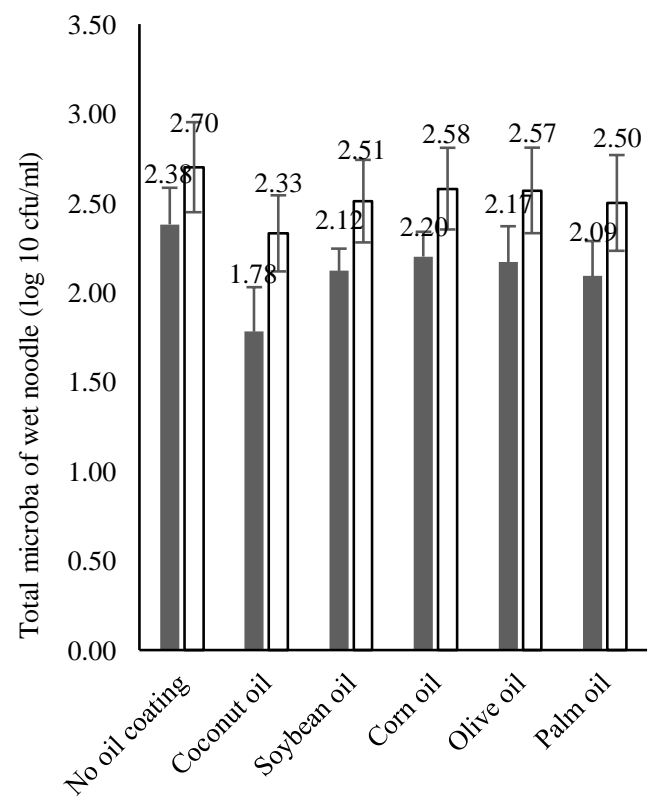

Figure 1. Microba total of uncoated and coated wet noodle with vegetables oil: fresh $(\square)$ and after $48 \mathrm{~h}$ storage $\square$ ) 


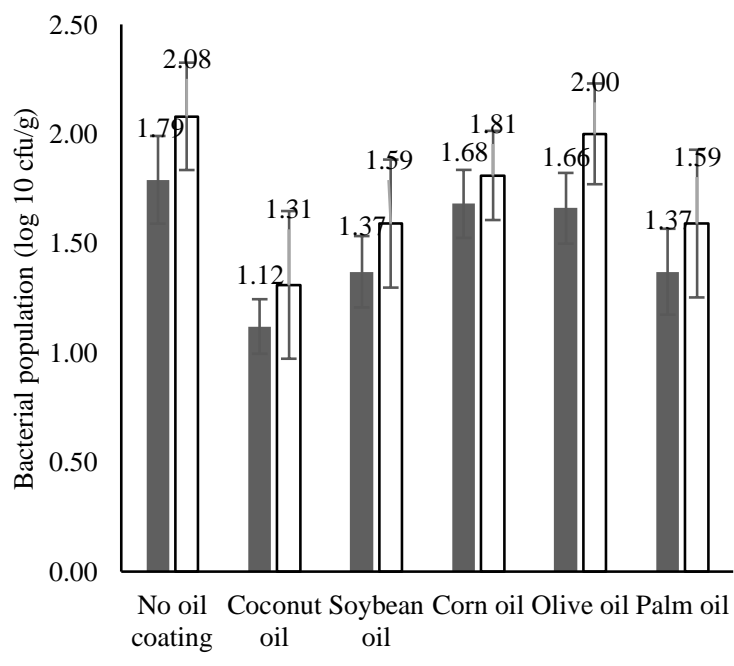

Figure 2. Bacterial population of uncoated and coated wet noodle with vegetables oil: fresh $\square$ and after 48 h storage $\square$

\subsection{Water content of wet noodle coating by vegetables oil}

The coated wet noodles using vegetable oil resulted in a lower water content than without oil coating (Figure $3)$. The highest water content occurred on uncoated wet noodles or control $(67.43 \%)$, while the lowest water content was obtained on coated wet noodles with corn oil (57.68\%). Shilling et al. [14] reported that the presence of oil can prevent microbial contamination due to the fatty acid content which acts as an antimicrobial. Bobinski et al. [4] also reported that lauric acid $10 \%$ can reduce the microbial population of the strains of Pseudomonas aeruginosa, Staphylococcus aureus, and Escherichia coli[4].

\subsection{Elasticity of wet noodle coating by vegetables oil}

The coated wet noodles using vegetable oil affects the value of its elasticity. The highest elasticity was found in wet noodles with soybean oil coating $(0.16 \%)$. Coating with coconut oil produces elasticity similar to wet control noodles without coating (Figure 4). Setyawardhani, et al.[14] concluded that each type of vegetable oil has different characteristics depending on the fatty acid content which can affect the characteristics of the resulting product as well. The type of packaging must also be considered to maintain product characteristics. Water can migrate from the product to the environment which can cause changes in its elasticity (Kusnandar et al. 2010).

\subsection{Texture of wet noodle coating by vegetables oil}

The texture of wet noodles without vegetable oil coating or control was $13.1 \mathrm{~g} / \mathrm{mm}$ while wet noodles that had been coated with vegetable oil had a lower texture of $10.66 \mathrm{~g} / \mathrm{mm}$ (Figure 5). According to Sampebarra et al.[15], the fat content in the oil can cause the product to become softer or softer. Hou[7] explained that noodle making need $2 \%$ of vegetable oil to improve the noodle texture.

\subsection{Sensory characteristics of wet noodle coating by vegetables oil}

Descriptive sensory evaluation was carried out on wet noodles to determine the effect of vegetable oil coating on the taste in the form of color, texture, aroma, and taste (Figure 6). The results of the chi-square test $(\alpha \leqslant 0.05)$ showed that the color of coated wet noodles with vegetable oil coating produced the highest value of 4.96 . The preference color of wet noodles was obtained on coated wet noodles with soybean oil $(4,96)$. The color is more bright. Hou[7] states that the dark colors are not preferred while the bright colors will be more attractive and likeable.

Therefore, the panelists prefer the color of wet noodles with soybean oil coating because it produces a bright color when compared to wet noodles without other vegetable oil coatings. This can be caused by the color of noodles in general which has been known for a long time by the public as yellowish noodles. Scent greatly determines the delicacy of food and affects its acceptance. Food that is not accompanied by an unpleasant odor will reduce its acceptance[16].

The results of the chi square test $(\alpha \leqslant 0.05)$ for the assessment of preference for the aroma of wet noodles resulted in the highest value being wet noodles coated with olive oil $(4,32)$. Olive oil has the aroma of fresh olives from the content of squalene compounds as described. Squalene is an organic substance in the form of liquid ether but not oil because it does not contain fatty acids or $\mathrm{COOH}$ (carboxyl) groups, thus producing a distinctive aroma [17].

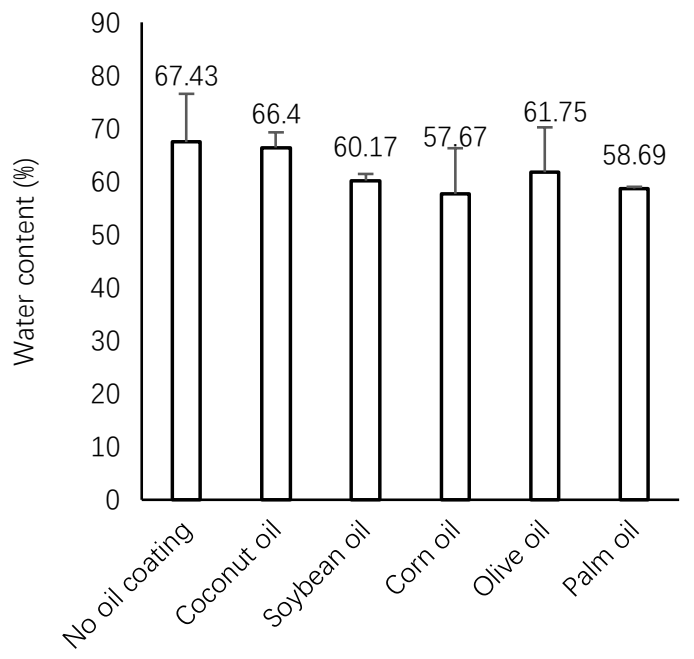

Figure 3. Water content of uncoated and coated wet noodle with vegetables oil 


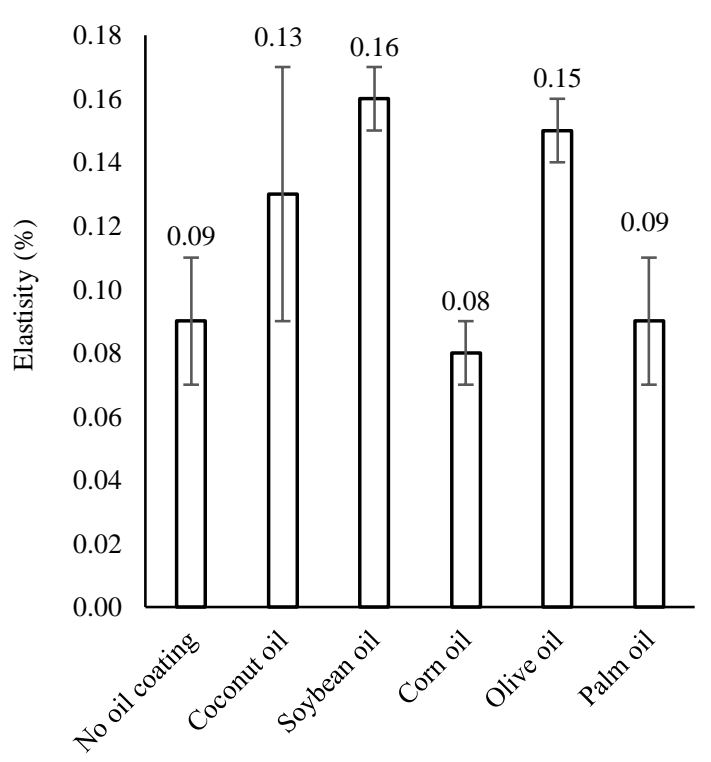

Figure 4. Elasticity of uncoated and coated wet noodle with vegetables oil

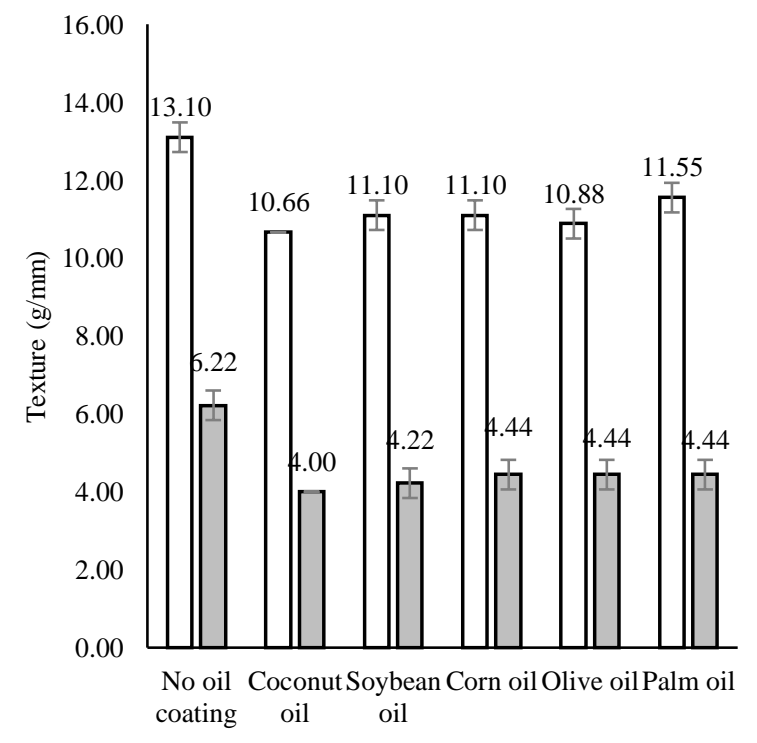

Figure 5. Texture of uncoated and coated wet noodle with vegetables oil: fresh $\square$ ) and after 48 h storage

The assessment of preference for wet noodle texture resulted in the highest value of 4.44 for coating with palm oil. Panelists do not like wet noodles with a texture that is too soft. Uncoated wet noodles produce a coarser texture, while the coated wet noodles have more breaks texture. The fat content in the oil can cause the product to become softer[15]. The taste of a product affects the level of consumer acceptance. The assessment of the preference for the wet noodle taste resulted in the highest value of 4.60 for coated wet noodles with olive oil. Wu et al.,[18] reported that oil content was correlated to the starch gel hardness, gumminess and chewiness, while pasting properties were negatively correlated.

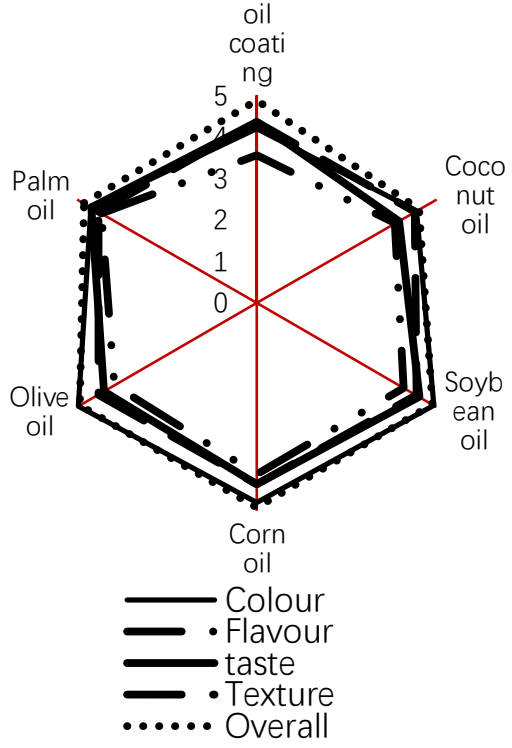

Figure 6. Sensory score of uncoated and coated wet noodle with vegetables oil

\section{CONCLUSION}

The biosafety of wet noodles produced by using vegetable oil coating was at a safe level below the maximum allowable limit of Indonesian national standards (less than $10^{6} \mathrm{CFU} / \mathrm{g}$ ). Total microbes of wet noodles with coconut oil coating are $2.70 \mathrm{log} \mathrm{CFU} / \mathrm{g}$, while olive oil with total microbes are $2 \log \mathrm{CFU} / \mathrm{g}$. The lowest bacterial contamination was in wet noodles coated with coconut oil after 48 hours of storage as much as 1.31 $\log \mathrm{CFU} / \mathrm{g}$. Moisture content of wet noodles reaches up to $67.43 \%$. The elasticity of wet noodles becomes more easy to break after 48 hours of storage. The coating of vegetable oil on wet noodles did not affect the sensory characteristics. Further research needs to be done to determine the nutritional value and digestibility of noodles coated with vegetable oil

\section{ACKNOWLEDGMENTS}

Thanks to Universitas Jember that funding theses research through the Grant of Research Group 2021 to Kelompok Riset (KeRis) Pangan ASUH (Aman Sehat Utuh Halal).

\section{REFERENCES}

[1] Fauziah, R. R. (2014). Kajian keamanan pangan bakso dan cilok yang beredar di lingkungan universitas jember ditinjau dari kandungan boraks, formalin dan TPC. Jurnal Agroteknologi, 8(01), 6773. 
[2] Koswara, S. 2009. Teknologi Pengolahan Telur (Teori dan Praktek), eBookPangan.com. diakses pada tanggal 15 Juni 2020.

[3] Shilling, M., Matt, L., Rubin, E., Visitacion, M. P., Haller, N. A., Grey, S. F., \& Woolverton, C. J. (2013). Antimicrobial effects of virgin coconut oil and its medium-chain fatty acids on Clostridium difficile. Journal of medicinal food, 16(12), 10791085.

[4] Bobiński, R., Pielesz, A., Kawecki, M., \& Staniszewski, L. (2020). The effect of lauric acid on pathogens colonizing the burn wound: a pilot study. Alternative therapies in health and medicine, 26(2), 23-27.

[5] Dwiputra, D., Jagat, A. N., Wulandari, F. K., Prakarsa, A. S., Puspaningrum, D. A., \& Islamiyah, F. (2015). Minyak jagung alternatif pengganti minyak yang sehat. Jurnal Aplikasi Teknologi Pangan, 4(2).

[6] Dwiputra, D., Jagat, A. N., Wulandari, F. K., Prakarsa, A. S., Puspaningrum, D. A., \& Islamiyah, F. (2015). Minyak jagung alternatif pengganti minyak yang sehat. Jurnal Aplikasi Teknologi Pangan, 4(2).

[7] Hou, G. G. (2020). Processing technology of wheat flour noodle. In Asian Noodle Manufacturing (pp. 43-62). Woodhead Publishing

[8] Jackson, G.J., Merker, R.I., Bandler, R. (2001). Bacteriological Analytical Manual, 8th Edition, Revision A, Office of Special Research Skills, CFSAN, FDA.

[9] Nurhayati, N., Oktavianto, A., Suswati, E. (2018a). Effectiveness of Low Thermal Destruction on Drinking Water Contain Enteropathogenic Bacteria Isolated from Wellspring at Mojo VillageLumajang Regency-Indonesia. International Journal of Sustainable Future for Human Security. 6 (1): 15-19

[10] Nurhayati, N., Maryanto, M., \& Gandaningrum, L. (2018b). Sensory and Chemical Characteristics of Bar Cookies Made from Mung Bean Flour and Ripe Plantain var Raja as Emergency Food. Pertanika J. Trop. Agric. Sc. 41 (3): 1413 - 1422

[11] Nurhayati, N., Belgis, M., Suswati, E., \& Purwandari, U. (2019). Application of RTU Media for Biosafety of Mie Lethek, Indonesian BendoCassava Noodles, Based on Chromogenic Agar. Proceedings of The Second International on Food and Agriculture ISBN : 978-602-14917-9-9: 329333

[11] Dalu, K. C. A., Nurhayati, N., \& Jayus, J. (2019). In vitro modulation of fecal microflora growth using fermented "pisang mas" banana and red guava juices. Current Research in Nutrition and Food Science Journal, 7(2), 449-456.

[12] Meilgaard, M., Civille, G. V., \& Thomas, B. (1999). Sensory Evaluation Techniques. Florida, USA: CRC Press LLC.

[13] Nurhayati, N., Maryanto, M., \& Gandaningrum, L. (2018b). Sensory and Chemical Characteristics of Bar Cookies Made from Mung Bean Flour and Ripe Plantain var Raja as Emergency Food. Pertanika J. Trop. Agric. Sc. 41 (3): 1413 - 1422 (2018)

[14] Setyawardhani, D. A., Distantina, S., Sulistyo, H., \& Rahayu, S. S. (2007). Pemisahan asam lemak tak jenuh dalam minyak nabati dengan ekstraksi pelarut dan hidrolisis multistage. Ekuilibrium, 6(2), 59-64.

[15] Sampebarra, A. L., Khaerunisa, K., Ristanti, E. Y., \& Asriati, D. W. (2019). Karakteristik Cokelat Spread dengan Penambahan Oleogel dari Oleogator Lemak Kakao. Jurnal Industri Hasil Perkebunan, 14(2), 24-32.

[16] Li, D., Jia, J., \& Wang, X. (2020). Unpleasant food odors modulate the processing of facial expressions: An event-related potential study. Frontiers in neuroscience, 14, 686.

[17] Beltrán, G., Bucheli, M. E., Aguilera, M. P., Belaj, A., \& Jimenez, A. (2016). Squalene in virgin olive oil: screening of variability in olive cultivars. European Journal of Lipid Science and Technology, 118(8), 1250-1253.

[18] Wu, J., Aluko, R. E., \& Corke, H. (2006). Partial least-squares regression study of the effects of wheat flour composition, protein and starch quality characteristics on oil content of steamed-and-fried instant noodles. Journal of Cereal Science, 44(2), 117-126. 